\title{
RENEWABLE VS NON-RENEWABLE ENERGY CONSUMPTION AS A DRIVER OF GOVERNMENT DEFICIT IN NET ENERGY IMPORTING COUNTRIES
}

\author{
Can Tansel Tugcu ${ }^{1+}$ \\ Angeliki N. Menegaki ${ }^{2}$ \\ Ilhan Ozturk ${ }^{3}$
}

\author{
${ }^{\prime}$ Faculty of Economics and Administrative Sciences, Akdeniz University, \\ Antalya-Turkey. \\ ${ }^{2}$ Cyprus Open University, Nicosia, Cyprus. \\ ${ }^{s}$ Agricultural University of Athens, Department of Regional and Economic \\ Development; Faculty of Economics and Administrative Sciences, Cag \\ University, Mersin, Turkey.
}
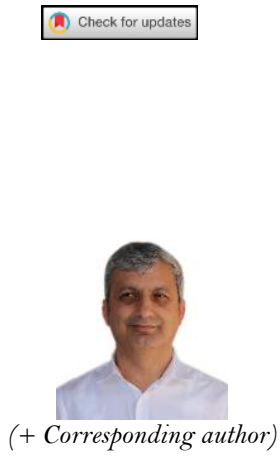

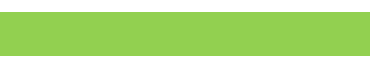

Article History

Received: 4 August 2020 Revised: 7 September 2020 Accepted: 9 October 2020 Published: 15 October 2020

\section{Keywords}

Economic growth Renewable energy Energy consumption Energy importers Fiscal effects.

JEL Classification: G21, G29, Q43.

\begin{abstract}
This paper is an empirical study on the relationship between renewable and nonrenewable energy sources on the central government budget deficit of 33 net energy importing energy countries. We employ a panel data framework with variables such as the budget deficit of the central government, the GDP per capita, the average official exchange rate, the real interest rate, renewable and non-renewable energy consumption for a data span from 2000 to 2012. Based on causality results from this study, there is a uni-directional effect from budget deficit towards renewable energy consumption and a bi-directional causal relationship between non-renewable energy consumption and the budget deficit. Results from our study are informative for policy making, since nowadays fiscal policy on energy consumption is worldwide disputed, for not being able to fully achieve its targets. Therefore, there is political willingness to re-design it and move it from energy subsidies and energy taxes into energy full cost pricing and other tools that aim to reach those social groups that are in more need.
\end{abstract}

Contribution/ Originality: This paper contributes to existing literature focusing on the relationship between renewable and non-renewable energy sources on the central government budget deficit of 33 net energy importing countries. It documents a uni-directional effect from budget deficit towards renewable energy and a bi-directional causal relationship between non-renewable energy and the budget deficit.

\section{INTRODUCTION}

Fiscal policy is generally known to be concerned with taxing (thus penalizing) «a bad behavior» and subsidizing (promoting) «a good behavior» with the aim to create distributional impacts for the benefits of the weakest and the general society welfare. Environmental economics theoretical paradigms provide a number of examples of "bad" and "good" behaviors of the economic agent and how these are transformed after the application of taxes and subsidies. Furthermore, fiscal instruments are more efficient in achieving the green goals as compared to legislation-based command and control measures. The latter has been greatly evidenced with the stimulation of renewable energies through the establishment of feed-in-tariffs.

The energy sector accounts for 35\% of all anthropogenic greenhouse emissions (IPCC, 2016). Fiscal policy with respect to energy is concerned with inducing the economic agent to consume clean energies, adopt energy efficient technologies, reduce greenhouse gas emissions, employ carbon sequestration, and increase the ability of natural 
systems to absorb more carbon and retard or stop climate change. At the same time these targets must be achieved without reducing employment, without reducing expenditure on health and education and without putting sustainable economic growth at stake. Sound fiscal policy is, or should, be utilizing full economic costing to calculate objectively the true benefits and costs to society from every possible cause, also applying the "polluter pays principle”.

Energy subsidies are currently equivalent to $6.5 \%$ of global GDP, which is more than what countries spend on healthcare all over the world (E.L, 2015). This situation cannot be justified at a moment when energy prices are so low, or when there is an urgent and binding need for emission reduction etc. Since it has been widely concluded that subsidies usually do not reach the social groups that are more in need of them, it might be better to remove them altogether and redirect that money into education, road infrastructure or other public investments. It has been estimated that if subsidies were completely eliminated, worldwide GDP would increase by 3.6\%. Understandably, it is easier to curtail subsidies when energy prices are falling, because the fall in subsidies will be outweighed by the revenue saved from lower prices. Governments move from the traditional subsidization and taxation to full market prices that reflect the true economic costs of the energy resource and its externalities.

In this paper we will focus on how renewable energies (juxtaposed to non-renewable energies) interact with governmental budget deficits and GDP. In particular, we are going to insert these aspects within the discussion for the energy-growth nexus. We will examine the question of "How does renewable energy consumption affect the budget deficit of the central government?” The rest of this paper is structures as follows: After the introduction (part 1), we will provide a literature review and a conceptual framework (part 2). Part 3 is the empirical analysis with results, while part 4 concludes the paper.

\section{A BRIEF LITERATURE REVIEW WITHIN A CONCEPTUAL FRAMEWORK}

Up to date the energy-growth nexus literature has not dealt with the topic we are embarking on with this paper. On the other hand, there is an increasing part of the energy-growth literature dealing with renewable energy and GDP growth. For example Irandoust (2016) has studied this relationship for Nordic Countries and found evidence for the neutrality hypothesis. This is not a surpise since Europe is a highly developed region and the neutrality hypothesis is usually confirmed in rich countries. The neutrality hypothesis has also been confirmed for Europe region by Menegaki. (2011). Additional renewable energy studies have been conducted by Lin and Moubarak (2014) for China, Ocal and Aslan (2013) for Turkey, Alper and Oguz (2016) for Europe, Destek (2016) for industrialized countries, Dogan and Ozturk (2017) for USA, Sharif, Raza, Ozturk, and Afshan (2019) for 74 countries, Ozcan and Ozturk (2019) for 17 emerging countries, Apergis and Payne (2011) for Central America, Apergis and Payne (2012) for eighty countries worldwide, Saidi and Mbarek (2016) for nine developed countries, Bhattacharya, Paramati, Ozturk, and Bhattacharya (2016) for 38 countries worldwide, Chang et al. (2015) for G7 countries, Marques and Fuinhas (2012) for 24 European countries and Bulut and Menegaki (2020) for solar energy in top ten countries with highest installed capacity etc. Most importantly, Sebri (2015) provides a meta-analysis and overview of renewable energy growth nexus studies and pinpoints some of the reasons of the variability of the results produced from this field of studies which sometimes produces mixed and controversial results (Menegaki, 2014).

Another tendency in the renewable energy growth nexus field is to study specific types of renewable energy with respect to their causality to and from economic growth. Examples of this tendency are by Apergis, Chang, Gupta, and Ziramba (2016) focusing only on hydroelectricity from the ten largest producers worldwide, Bilgili and Ozturk (2015) focusing only on biomass from G7 countries, Ozturk and Bilgili also on biomass from Sub-Saharan Africa (2015), Shahbaz, Rasool, Ahmed, and Mahalik (2016) on biomass from the BRICS region, Bildirici (2013) in ten developing countries etc. The scope for these studies is huge, considering the variety of the types of renewable energy, the various economic sectors applicable in one economy as well as the various measures of economic activity 
and the variables characterizing the production function of an economy in each case. For example Ohler and Fetters (2014) provide an all inclusive study of various constituents of renewable energy and GDP growth for 20 OECD countries.

Typically renewable energy-growth studies are concerned with finding the direction of causality between renewable energy as a whole, or its particular types, and a measure of economic activity which is usually the GDP growth. Recently however, new measures of economic activity have entered the scene of this major research field; For example Marques, Fuinhas, and Menegaki (2016) and Marques., Fuinhas, and Menegaki (2014) have perused industrial production with respect to which they study renewable energy produced electricity. To go a bit further, Menegaki and Tugcu (2016) or Menegaki and Tiwari (2017) have started replacing the conventional measure of economic activity used in the energy-growth nexus, such as the GDP, with an Index for sustainable Economic Welfare, the so-called ISEW.

Up to date the energy-growth nexus literature or the renewable energy-growth literature has not studied the effects of renewable energy with respect to the budget deficit of central governments. Instead, there are energygrowth nexus studies that include magnitudes of a financial nature. For example the energy-growth nexus has hosted the effects of financial development (Khan, Khan, Zaman, Irfan, \& Khatab, 2015; Komal \& Abbas, 2015; Kumar, Stauvermann, Loganathan, \& Kumar, 2015; Rafindadi \& Ozturk, 2016; Tang \& Tan, 2014) or banking development in the nexus (Aslan, Apergis, \& Topcu, 2014) but none of the existent studies, to the best of our knowledge, has investigated of renewable energy to the budget deficit of the central governments and vice-versa.

Studying the effects of the budget deficit leads the analysis to fiscal stability. This is a very important gap to be filled in the literature, because energy policy makers need to be prepared on the effects of energy tax and subsidy reforms on fiscal stability, state finances and government debt. Also, this is the reason we have entitled this section as "A brief literature review and a conceptual framework" instead of the usual title of "Literature review". We did this because literature review on this specific relationship between renewable energy and government deficit is, to the best of our knowledge, non-existent and we deem necessary to devote some space in this manuscript placing the conceptual framework of this piece of research and thus merging it with a brief literature review.

Fiscal policy affects financial stability and consequently the budget deficit. Energy fiscal policy is the set of measures and instruments for the pricing of externalities arising from the consumption of fossil fuel energies and the subsidies for the support of clean or renewable energies.

\subsection{Energy Taxes}

Energy taxes can play a role for the promotion of renewable energies and the contraction of fossil energy consumption. Energy use is taxed on a Pigouvian perspective (for the damage it causes through its atmospheric emissions), namely taxes are used to internalize external costs, but also because of fiscal convenience, namely because energy is a necessity good and has a very low elasticity of demand, at least on the short run. Each country taxes energy consumption based on its resource endowments, the prevalent views on income distribution and the different needs and capabilities to raise fiscal revenue.

Across OECD countries, average tax rates on energy use are $€ 3.28$ per Gigajoule (GJ) while the average tax rate on carbon is $€ 52.04$ per ton of $\mathrm{CO} 2$ (OECD, 2013). The highest energy and carbon taxes are observed in Europe, because the 2003 European Energy Taxation Directive 2003/96/EC has set minimum taxation rates (European Commission, 2003). Among the different economic sectors, energy use in transport is taxed higher (compared to the energy it uses and the carbon it releases). This is not the same with the energy used in industry and households, whereby different trends apply. Namely some countries tax higher the energy use spent in industry while others tax higher the energy spent by the domestic sector.

Nowadays it is widely acknowledged that a revision and re-appraisal is required on energy taxes, because not all of them have been successful in the implementation of their targets (OECD, 2013). Technology change and price 
changes together with the economic recession afflicting many countries worldwide have rendered energy too expensive for some social groups. For example, fuel in agricultural activities is exempt from energy taxes in various countries, thus contributing to energy squandering. Some other countries apply a very low tax rate on coal (compared to other heating fuels), regardless of its acute externalities. Table 1 provides a summary of the average tax rates applying in OECD countries in three major energy sectors. The Table 1 reports tax rates for energy consumption per se separately from the taxes on the externality of $\mathrm{CO}_{2}$ emissions. Carbon taxes are expected to shift electricity generation from fossil fuel sources to renewable energy sources or encourage investment in energy efficiency technologies.

Table-1. Average tax rates for OECD countries.

\begin{tabular}{c|c|c}
\hline Energy uses & Energy use & CO $_{2}$ emissions \\
\hline Heating \& process use & $39 \%$ & $46 \%$ \\
\hline Transport & $23 \%$ & $27 \%$ \\
\hline Electricity & $38 \%$ & $27 \%$ \\
\hline
\end{tabular}

Some countries are using fiscal restructuring in order to handle budget deficits and reduce their debt-to- GDP ratio. For example, Germany uses environmental taxes revenue to reduce labor costs and thus the creation of more jobs (UNEP, 2011). EU28 and Norway accrue a significant part of government revenue from fossil fuels. Particularly oil has contributed about €330b to government revenue in 2014, while renewable such as solar and wind are net recipients of support (NERA Economic Cosulting, 2014).

\subsection{Energy Subsidies}

Taxes alone cannot fulfill their energy or environmental goals. Some actions of the economic agent cannot be directly measured or monitored. Therefore, when information costs are too high, subsidies can come into play and correct the inefficiencies energy taxes could not. Thus, subsidies supplement taxes. Typically, subsidies solve the problem of affordability some economic agents are confronted with or the lack of information and understanding consumers may have for energy efficient technologies etc.

However, subsidies are not only direct payments from governments. They can take various forms. They can take place through trade restrictions, the imposition of certain price conditions and etc. For example, the application of feed-in-tariffs was a means of subsidization towards renewable energies. The privatization of energy companies are also a means of rationalizing energy markets by reducing their costs and their subsidy needs. Thus, users and not-tax payers will pay the cost for the new infrastructure. Subsidies are financed by taxes or by reducing public expenditure. Both taxes and subsidies may cause rebound effects. For example, if a tax is too low or a subsidy too high may cause the reverse result from what it was initially designed to do.

Energy subsidization is high in the worldwide. For example, petroleum subsidization was US $\$ 200$ billion in 2011 and removal or reduction of fossil fuel subsidies could reduce greenhouse gas emissions by $6 \%$ in 2050 (UNEP, 2011). Besides, energy subsidies are not supposed to be doing a quite good job in benefiting the financially poorest groups, since it has been estimated that only the $8 \%$ of the subsidies granted in 2010 , reached the $20 \%$ poorest population. Moreover, according to IEA, in 2014 fossil fuel consumption subsidies amounted to \$493 billion in 2014 and they were four times higher than the subsidies for renewable energies. Subsidies for oil are half of that amount (International Energy Agency, 2016). Subsidies on fossil energy do not make much sense, since societies need to move to cleaner energies and avoid resource wasteful consumption.

Based on Barany and Grigonyte (2015) Central and Eastern Europe and the Commonwealth of Independent States account for $15 \%$ of global subsidies while India is the third largest subsidizer in the world after Iran and Saudi Arabia. The USA, in absolute terms are the largest subsidizer, but in post-tax terms, subsidies in that country 
amount to $2.7 \%$ of GDP which remains a high percentage for a developed country such as this. The EU27 have the lowest subsidies worldwide but this is due to the higher energy and environmental taxes in this region.

Coal in Europe had been long subsidized to render internal production more competitive than the imported one. Nowadays, subsidies have been moved from fossil fuels to renewable energies. Subsidies on fossil energy fuels secure their usage by poor groups but at the same time they increase emissions because they do not transmit the correct signals to consumers about the scarcity of the resource and its environmental impacts. Subsidies to producers are common in OECD countries, while subsidies to consumers are common in non-OECD countries. In most OECD countries energy subsidies are more than offset by taxes, levied mainly on oil products (UNEP, 2008). Subsidies can take the forms of grants or tax exemptions which may put the government budgets under pressure. The different forms of taxes and subsidies can take are displayed in Figure 1.

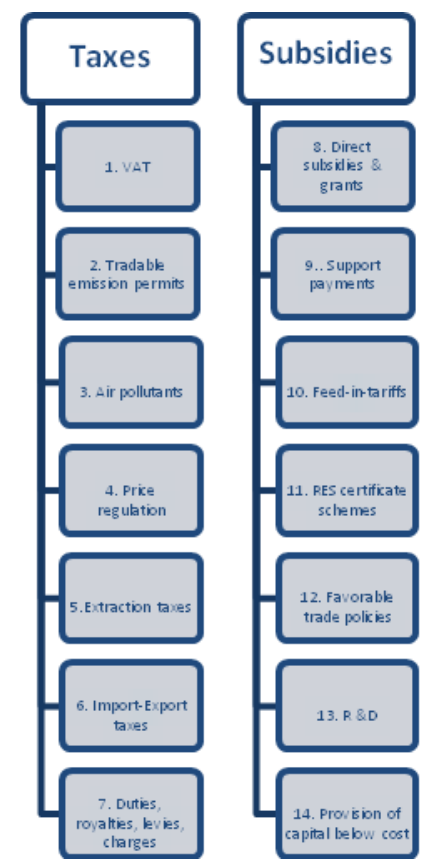

Figure-1. Financial flows to energy (subsidies) and financial flows from energy (taxes).

Below we explain briefly what each type of tax and subsidy stands for in Figure 1.

VAT: Generally, countries which peruse VAT in their national taxation, can manipulate it in ways to serve their national energy and environmental policies (Finnish Energy Industries, 2011). For EU countries, the energy taxation Directive sets the minimum excise duty rates that apply for energy (European Commission, 2003). Also, concessionary VAT rates can apply for energy saving products such as insulation materials, wind turbines and etc. (GovUK, 2016).

Tradable emission permits: Tradable emission permits constitute another instrument for pollution control, broadly established after the Kyoto protocol. Unlike taxes which act as a penalty to air polluting activities, the concept of tradable emission permits relies on the decision of a certain level of emissions and then the respective pollution rights are offered in the market for bidding.

Air pollutants: Taxes on air pollutants are an indirect form of taxation to energy consumption. They place a charge on the air pollutants released into the atmosphere. Usually they are measured in dollars (or other currency) per ton of carbon dioxide emitted or other greenhouse gases. The term fee, charge and tax are used interchangeably. Air pollution taxes leave the decision to the polluter to decide by how much they reduce the pollution they cause. Taxes are more direct, compared to pollution rights. 
Price regulation: Price regulation concerns either approval of prices or it involves the setting of price caps. Since it is not determined by the powers of demand and supply, price regulation bears distortion effects in market, but it is a useful tool for the protection of the weakest and the prevention of abuse from dominant business positions.

Extraction taxes: Energy extraction taxes compose significant fiscal revenue for fossil fuel energy producer countries. Sometimes lower fossil fuel prices or lower production influence downwards the respective fiscal revenue.

Import-export taxes: Depending on the macroeconomic and environmental targets each country pursuits, it sets import or export duties on fossil fuels.

Duties-royalties-taxes: When fossil fuels are regarded as a public good, governments collect royalties on the licensing of these sources. Royalties are charged as a percentage of the gross revenue originating from the source under construction.

Direct subsidies \& grants: Direct subsidies are direct cash transfers that aim to either reduce prices for consumers or to reduce costs for producers.

Support payments: Support mechanisms are mostly used in the renewable energies development. They encompass quota based support where electricity producers are obliged to produce a share of electricity from renewables, tender systems where a central planner issues an auction mechanism, net metering which is applicable for solar energy when single producers pay their electricity bills as the net difference of their electricity consumption minus the their solar energy production (OSCE, 2009).

Feed-in-tariffs: Feed-in-tariffs compose a particular support mechanism that guarantees grid access to single renewable energy consumers. They also secure long term contracts with local electricity utilities and they receive a guaranteed price for the energy they produce.

RES certificate schemes: RES certificate schemes are available to buyers of qualifying solar panels, wind or other renewable energy systems. Buyers can sell those certificates and get cash in return.

Favorable trade policies: An example of a sustainable energy trade agreement can contribute to the establishment of renewable energies among a group of countries that share the same climate change mitigation goals. That agreement could involve securing the import of cheap technology for the establishment of a renewable energy manufacturing sector in on country (Nampoothiri \& Manoharan, 2014).

R\&D: Research and development on smart grids, energy efficiency technologies, clean energies or other infrastructure constitutes a form of free capital provision.

Provision of capital below cost: Through cost subsidization, costs are lower for consumers or producers. One form of cost subsidization- besides direct cash transfers- is interest rate subsidization. It is highly probable that economies where evidence for the neutrality hypothesis applies, or the conservation hypothesis apply and thus energy appears as decoupled from growth, the change of energy fiscal policy will probably not change GDP growth. Conversely, economies with evidence for the growth or feedback hypothesis are the most prone to be affected by the revision of fiscal policy related to energy.

\subsection{The Economic Circuit and the Energy Fiscal Revenue/Cost}

A country economic circuit consists from households, businesses and the State. The three of them pay generally four types of taxes. We define them broadly as income taxes, payroll taxes and consumption taxes. Also, all three actors in economy pay energy or environmental taxes. All of these taxes generate fiscal revenue which, if less than fiscal expenses, creates budget deficit and gradually incurs debt. Conversely, if there is a surplus of fiscal revenue, growth is possible. According to the IMF (2014) some countries rely too much on the first three types of taxes (income, payroll and consumption) for the fulfillment of their fiscal targets and very few of their taxes are energy or environmental ones. The former sometimes hinder growth and this is the reason of the widely acknowledged need for the revision of current fiscal policy and the redesigning of energy taxes as smart fiscal tools. For example, 
according to the same source (IMF, 2014) a tax reform on fuels is estimated to be able reduce pollution deaths from fossil fuel emissions by $63 \%$ and will increase fiscal revenue up to $2.6 \%$ of GDP. Also, revenue from energy taxes can be recycled to other fiscal purposes or used specifically to finance energy-saving innovations.

Overall, energy efficiency, penetration of renewable energies and the greenhouse gas emissions are certainly key goals for several countries. Furthermore, some of these countries have set clear and binding objectives with respect to those targets. Nevertheless, the fiscal policy pertinent to these countries does not always favor the implementation of these goals, since fossil fuel energy is still significantly subsidized. Energy taxes are capable to induce technological innovation because they lead economic agents towards investing and buying of energy efficient goods and services. Energy taxes may also bear some side effects on other factors of production, for example the employment. Energy taxes can cause the so-called tax interaction effect, namely the redesign of fiscal policy may open up substitution possibilities that will either reduce growth or will increase it. A famous example of such a consequence is the simultaneous increase of employment and environmental quality (through its energy analogue), known as the "double dividend hypothesis".

Central Banks are responsible for the monetary policy of countries. Among their many different responsibilities, they are in charge of the money supply circulating in an economy, which in turn affects employment and growth. Also, they are in charge of the stability of the financial system of a country, the establishment of interest rates and the inflation. Figure 2 displays the above described mechanism in a macro-wide economic circuit. Therein, it can be seen how energy or other environmental revenue inflows or outflows affect the economic stability of a country and thus its GDP growth.

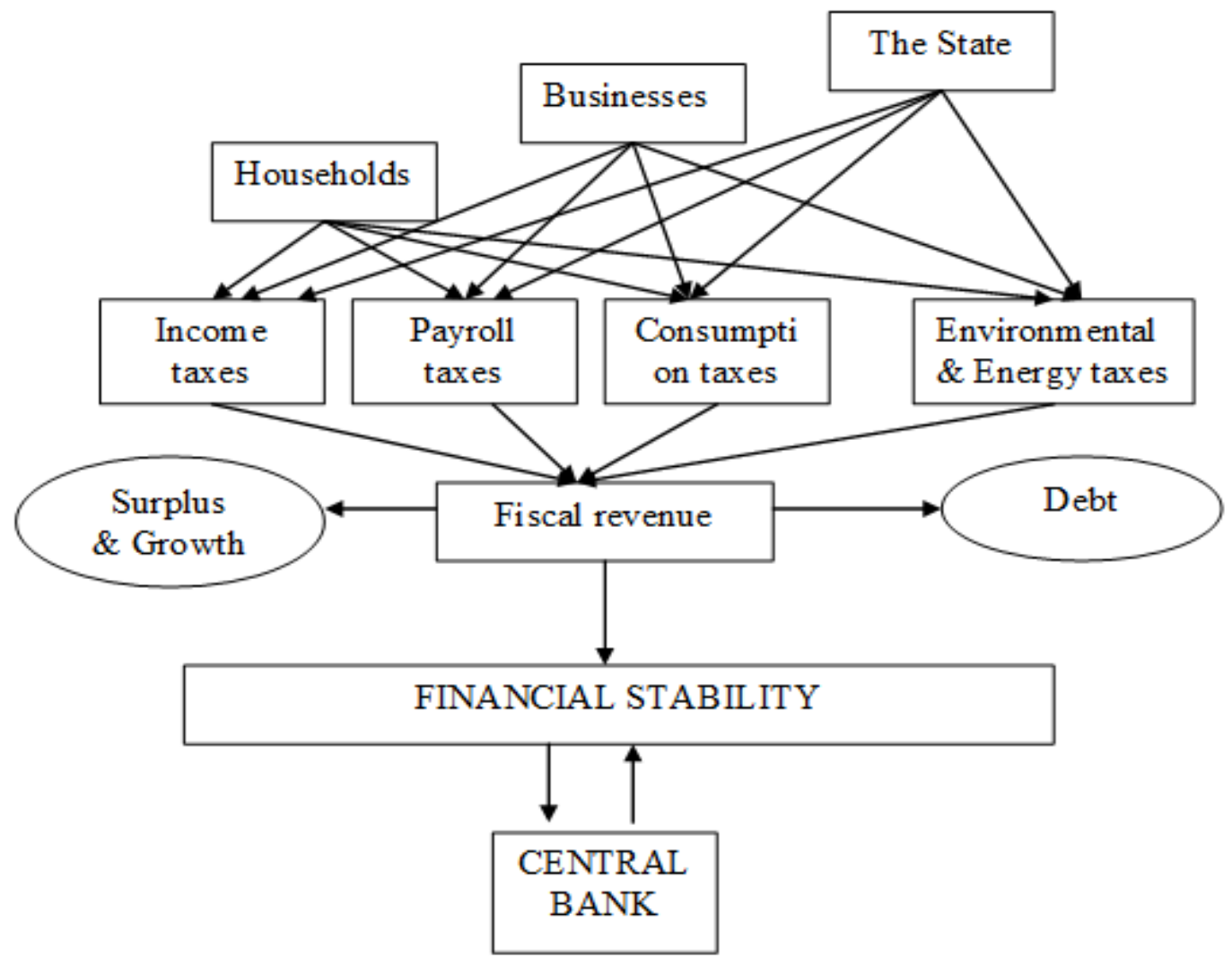

Figure-2. The economic circuit and energy fiscal revenue.

\section{EMPIRICAL ANALYSIS AND RESULTS}

\subsection{The Data}

The data set includes budget deficit (BD) of central government in current US dollars, GDP per capita (GDPPC) in current US dollars, average official exchange rate (EXCR) in local currency unit per US dollars, real 
interest rate (INTR), renewable energy consumption (REN), and non-renewable energy consumption (NREN) of 33 net energy importing countries ${ }^{1}$. All the data are sourced from the World Bank, World Development Indicators database. The data set covers annual panel data for the period of 2000-2012 and all variables are in natural logarithm.

\subsection{Descriptive Statistics}

Before proceeding to the empirical analyses, descriptive statistics of the variables under consideration are reported in Table 2. Results show that all variables are non-normally distributed; they are leptokurtic and negatively (BD, GDPPC, EXCR, REN, NREN) as well as positively skewed (INTR).

Table-2. Descriptive statistics.

\begin{tabular}{l|c|c|c|c|c|c}
\hline Descriptive statistics & BD & GDPPC & EXCR & INTR & REN & NREN \\
\hline Mean & -17.859 & 7.479 & 6.080 & 2.675 & 8.519 & 11.024 \\
\hline Median & -17.630 & 7.662 & 6.030 & 2.558 & 8.625 & 11.115 \\
\hline Maximum & -16.247 & 8.273 & 6.360 & 3.508 & 8.852 & 11.351 \\
\hline Minimum & -19.185 & 6.432 & 5.723 & 2.345 & 7.818 & 10.646 \\
\hline Std. Dev. & 0.952 & 0.663 & 0.210 & 0.320 & 0.281 & 0.247 \\
\hline Skewness & -0.001 & -0.335 & -0.027 & 1.276 & -1.243 & -0.419 \\
\hline Kurtosis & 1.921 & 1.486 & 1.590 & 3.967 & 3.678 & 1.656 \\
\hline Jarque-Bera & 15.983 & 48.978 & 35.547 & 133.262 & 118.740 & 44.837 \\
\hline (Prob.) & 0.000 & 0.000 & 0.000 & 0.000 & 0.000 & 0.000 \\
\hline
\end{tabular}

\subsection{Cross-Sectional Dependence}

One of the basic problems of panel data econometrics is cross-sectional dependence (CD). High degrees of globalization or cross-unit relations may give rise to the existence of this problem. In case of panel data that is cross-sectionally dependent, estimation results generally become inconsistent and upward-biased (Bai \& Kao, 2006). Thus, it is important to test the existence of cross-sectional dependence before any analysis.

The first approach for testing whether cross-sectional dependency exists in the data is to employ Breusch and Pagan's Lagrange multiplier (BPLM) test. Under the null of no cross-sectional dependence, this test has distributed asymptotically with chi-square. However, since the present study has 33 cross-section units, it is not possible to conduct this methodology, because this test is applicable only for the data set with small cross-section units.

To overcome the inefficiency of BPLM test, Pesaran (2004) developed an alternative methodology which is appropriate for the panels with large cross-section units. In this study, cross-sectional dependency (CD) test, which was developed by Pesaran (2004) is employed. Under the null of no cross-sectional dependence, this test is asymptotically distributed as standard normal and efficient for the case of large $\mathrm{N}$ and small $\mathrm{T}$. The CD test statistic proposed by Pesaran (2004) is as follows in Equation 1:

$$
C D=\sqrt{\frac{2 T}{N(N-1)}\left(\sum_{i=1}^{N-1} \sum_{j=i+1}^{N} \hat{p}_{i j}\right)}
$$

Where $\mathrm{T}$ is time interval, $\mathrm{N}$ is the number of cross-sections, and $\hat{p}_{i j}$ is pair-wise correlation between crosssections.

\footnotetext{
${ }_{1}$ These are Armenia, Bangladesh, Brazil, Croatia, Czech Republic, Dominican Republic, Estonia, Georgia, Iceland, Hungary, India, Israel, Jamaica, Jordan, Kenya, Kyrgyz Republic, Latvia, Lithuania, Moldova, Malta, Morocco, Nicaragua, Philippines, Poland, Romania, Slovak Republic, Slovenia, Switzerland, Thailand, Sweden, Ukraine, United States and Uruguay.
} 
According to test results given in Table 3, the null hypothesis is rejected even at $1 \%$ level of significance, indicating cross-sectional dependence in the data.

Table-3. Cross-sectional dependence.

\begin{tabular}{c|c}
\hline Test & Statistic \\
\hline CD & $72.663(0.00)$ \\
\hline Note: Number in parenthesis is p-value.
\end{tabular}

\subsection{Panel Cointegration}

In this study, the panel cointegration procedure developed by Westerlund (2007) was applied for investigating the existence of cointegration relationship among the variables in consideration. The two models in which the cointegration relationship is searched are as follows in Equations 2 and 3:

\section{$B D=F(G D P P C, E X C R, I N T R, R E N)$}

\section{$B D=F(G D P P C, E X C R, I N T R, N R E N)$}

Where BD is budget deficit, GDPPC is GDP per capita, EXCR is exchange rate, INTR is real interest rate, REN is renewable energy consumption and NREN is non-renewable energy consumption.

Westerlund (2007) developed four new panel tests with bootstrapping option, which accounts for the existence of long run relationships among integrated variables even in the case of cross-sectional dependence. The underlying idea is to test for the absence of cointegration by determining whether the individual panel members are error correcting. The considered error-correction model can be expressed as follows in Equation 4:

$$
\begin{gathered}
\Delta y_{i, t}=c_{i}+\alpha_{i, 1} \Delta y_{i, t-1}+\alpha_{i, 2} \Delta y_{i, t-2}+\ldots+\alpha_{i, p} \Delta y_{i, t-p}+\beta_{i, 0} \Delta x_{i, t}+\beta_{i, 1} \Delta x_{i, t-1}+\ldots+ \\
\beta_{i, p} \Delta x_{i, t-p}+\alpha_{i}\left(y_{i, t-1}-\beta_{i} x_{i, t-1}\right)+\mu_{i, t}
\end{gathered}
$$

Where $\alpha$ i provides an estimate of the speed of error-correction towards the long run equilibrium $y_{i, t}=-\left(\beta_{i} / \alpha_{i}\right) \times x_{i, t}$ for that series $\mathrm{i}$

The first two test statistics (i.e. panel statistics) of Westerlund (2007) test the null hypothesis "Ho: $\alpha \mathrm{i}=0$ for all I" against the alternative "H1: $\alpha \mathrm{i}<\mathrm{O}$ for all I", which indicates that rejection of Ho should be taken as evidence of cointegration for the panel as a whole. The second two statistics (i.e. group mean statistics) test the null hypothesis "Ho: $\alpha \mathrm{i}=\mathrm{O}$ for all I" against the alternative "H1: $\alpha \mathrm{i}<\mathrm{O}$ for at least one I", suggesting that rejection of Ho should be taken as evidence of cointegration for at least one of the cross-sectional units. The two panel statistics are as follows in Equations 5 and 6:

$$
\begin{aligned}
& P_{r}=\frac{\hat{\alpha}_{i}}{S E\left(\hat{\alpha}_{i}\right)} \\
& P_{\alpha}=T \hat{\alpha}
\end{aligned}
$$

where $\hat{\alpha}_{i}$ is the estimated value of error correction parameter and $S E\left(\hat{\alpha}_{i}\right)$ is the conventional standard error ${ }_{\text {of }} \hat{\alpha}_{i}$. The two group mean statistics are as follows in Equations 7 and 8 : 


$$
\begin{gathered}
G_{r}=\frac{1}{N} \sum_{i=1}^{N} \frac{\hat{\alpha}_{i}}{S E\left(\hat{\alpha}_{i}\right)} \\
G_{\alpha}=\frac{1}{N} \sum_{i=1}^{N} \frac{T \hat{\alpha}_{i}}{\hat{\alpha}_{i}(1)}
\end{gathered}
$$

where $\hat{\alpha}_{i}(1)=1-\sum_{j=1}^{P_{i}} \hat{\alpha}_{i j}$ and $S E\left(\hat{\alpha}_{i}\right)$ is the conventional standard error of $\hat{\alpha}_{i}$.

According to Westerlund (2007) in addition to allowing for cross-sectional dependence, each test is able to accommodate individual-specific short run dynamics, including serially correlated error terms, non-strictly exogenous regressors, individual-specific intercept and trend terms, and individual-specific slope parameters. These tests also have good small-sample properties with small size distortions and high power relative to other popular residual-based panel cointegration tests (e.g. Pedroni (2004)).

According to three of four test statistics reported in Table 4, there exists a statistically significant cointegration relationship even at $1 \%$ level of significance for the models.

Table-4. Panel cointegration test results.

\begin{tabular}{c|c|c}
\hline \multicolumn{3}{c}{ Table-4. Panel cointegration test results. } \\
\hline Tests & REN & NREN \\
\hline $\mathbf{P}_{\mathbf{r}}$ & $-4.395(0.00)$ & $-7.208(0.00)$ \\
\hline $\mathbf{P}_{\boldsymbol{\alpha}}$ & $-12.269(0.37)$ & $-14.300(0.01)$ \\
\hline $\mathbf{G}_{\mathbf{r}}$ & $-19.169(0.00)$ & $-18.148(0.00)$ \\
\hline $\mathbf{G}_{\boldsymbol{\alpha}}$ & $-13.375(0.00)$ & $-14.722(0.00)$ \\
\hline
\end{tabular}

\subsection{Panel Estimation}

Given that the variables are cointegrated, the next step is to estimate the long-run parameters. In case of having cross-sectional dependence, serial correlation and endogeneity problems, using the panel OLS estimator for estimating panel cointegration regression may last with biased results. In this sense, Kao and Chiang (2000) and Pedroni (2000) suggested utilizing the fully modified OLS (FMOLS) and dynamic OLS (DOLS) estimators for the panel estimation. The present study employed the FMOLS and DOLS methodologies and findings were reported in Table 5. Accordingly, consuming renewable energy is the factor that increases the budget deficit whereas nonrenewable energy consumption decreases.

Table-5. Panel estimation results (dependent variable: BD).

\begin{tabular}{c|c|c|c|c}
\hline \multirow{2}{*}{$\begin{array}{c}\text { Independent } \\
\text { variables }\end{array}$} & \multicolumn{3}{|c}{ Estimator } \\
\cline { 2 - 5 } & \multicolumn{2}{|c}{ DOLS } & $0.405(0.02)$ & $4.761(0.00)$ \\
\hline GDPPC & $4.827(0.00)$ & $12.981(0.00)$ & $3.164(0.00)$ & $2.489(0.00)$ \\
\hline EXCR & $12.803(0.00)$ & $25.481(0.00)$ & $3.825(0.00)$ & $3.672(0.00)$ \\
\hline INTR & $15.628(0.00)$ & $17.417(0.00)$ & $6.100(0.00)$ & $-11.510(0.00)$ \\
\hline REN & $5.655(0.00)$ & & & FMOLS \\
\hline NREN & \multicolumn{3}{|c}{$-6.523(0.00)$} &
\end{tabular}

Note: a Akaike information criterion was used to determine the optimal lag and lead lengths. ${ }^{b}$ Numbers in parentheses are p-values. 


\subsection{Panel Causality}

Panel cointegration test results allowed for the investigation of causality between renewable and nonrenewable energy consumption and total factor productivity growth as the final step of the analysis. To this end, recently developed panel Granger causality test by Dumitrescu and Christophe (2012) was employed.

Dumitrescu and Christophe (2012) proposed a panel causality test based on the individual Wald statistic of Granger non-causality averaged across the cross-section units. Testing procedure allows considering the heterogeneity of causal relationships and the heterogeneity of regression model used for testing Granger causality. The linear panel regression model followed by Dumitrescu and Christophe (2012) is as follows in Equation 9:

$$
\mathrm{y}_{\mathrm{i}, \mathrm{t}}=\alpha_{i}+\sum_{j=1}^{J} \lambda_{i}^{j} y_{i, t-j}+\sum_{j=1}^{J} \beta_{i}^{j} x_{i, t-j}+\varepsilon_{i, t}
$$

Accordingly, Dumitrescu and Christophe (2012) states that "a homogeneous specification of the relation between the variables $\mathrm{x}$ and $\mathrm{y}$ does not allow to interpret causality relations if any individual from the sample has an economic behavior different from that of the others". Thus, they propose an average Wald statistic which tests the null of no causal relationship for any of the cross-section units $\left(H_{0}: \beta_{i}=0,(i=1, . ., N)\right)$, alternative hypothesis that causal relationships occur for at least one subgroup of the panel $\left(H_{1}: \beta_{i}=0,\left(i=1, . . N_{1}\right) ; \beta_{i} \neq 0,\left(i=N_{1}+1, N_{1}+2, . ., N\right)\right)$. Rejection of the null hypothesis with $N_{1}=0$ indicates that x Granger causes y for all i, whereas rejection of the null hypothesis with $N_{1}>0$ provides evidence that the regression model and the causal relations vary from one individual or the sample to another. Under these circumstances, the average of individual Wald statistic generated by Dumitrescu and Christophe (2012) is in the following manner as shown in Equation 10:

$$
W_{N, T}^{H n c}=\frac{1}{N} \sum_{i=1}^{N} W_{i, T}
$$

where $W_{i, T}$ is the individual Wald statistic for the i-th cross-section unit.

Table 6 shows the panel causality test results. Estimates proved that there exists a bi-directional causal relationship between non-renewable energy consumption and budget deficit. On the other hand, the causal link between renewable energy consumption and budget deficit is uni-directional running from budget deficit to renewable energy consumption.

Table-6. Panel causality test results.

\begin{tabular}{c|c|c|c|c}
\hline Energy source & Energy $\rightarrow$ BD & Causal & BD $\rightarrow$ Energy & Causal \\
\hline REN & $0.766(0.20)$ & No & $0.057(0.01)$ & Yes \\
\hline NREN & $0.339(0.04)$ & Yes & $0.222(0.02)$ & Yes \\
\hline Note: a Numbers in parenthesis are p-values.
\end{tabular}

\section{CONCLUSION AND POLICY IMPLICATIONS}

This study aims at investigating the long and the short-run relationships between renewable and nonrenewable energy consumption and budget deficit in 33 net energy importing countries for the period of $2000-2012$. To this end, the panel cointegration procedure developed by Westerlund (2007) the fully modified OLS and 
dynamic OLS estimators, and finally the panel Granger causality test by Dumitrescu and Christophe (2012) were employed.

The panel cointegration analysis proved that energy variables and budget deficit have the same growth path over in the long-run. And panel estimates indicated that renewable energy consumption is the factor that increases the budget deficit whereas consuming non-renewable energy sources decreases it. Besides, the causality analysis showed that the causal link between renewable energy consumption and budget deficit is uni-directional running from budget deficit to renewable energy consumption, and there exists a bi-directional causal link between nonrenewable energy consumption and budget deficit.

The aforementioned results imply a policy that strengthens the consumption of renewable energy has a detractive effect on the fiscal stability. This is again one of the cases where environmental and economic issues collide. Although it is accepted that the consumption of renewable energy sources is favorable in terms of reducing $\mathrm{CO} 2$ emissions and protecting the environment, by increasing the budget deficit it damages fiscal stability and weakens the possible growth effect that may emerge on the GDP per capita. There may be three possible explanations for the existence of this result. The first one is subsidies. It is well known that net energy importing countries strongly subsidy the consumption of renewable energy sources. This creates a fiscal burden for the budget. Second, governments generally are not willing or able to put taxes on the consumption of renewable energy sources. Since it is subsided but not taxed, the deficit that is emerged by the consumption of renewable energy sources increases. Third, since the production of renewable energy mostly requires high-tech intermediate goods, governments also subsidy the production or importing of these inputs. Without taxing, this is the last burden channel that renewable energy consumption creates on the central government budget. The combination of these explanations reaches us two possible solutions in order to solve the negative effect of renewable energy consumption on the budget deficit. The first one is to limit the subsidies, and the second one is to tax renewable energy consumption. Since it does not seem easy to tax renewable energy consumption in the short-run, reducing subsidies may be more plausible for the solution of the considered issue. But in the long-run, governments should find a way to tax the renewable energy consumption.

On the other hand, given the negative impact of non-renewable energy consumption to the environment, it is well known that consuming non-renewable energy sources positively affects the GDP per capita. Additively, this study proved its positive contribution to the fiscal stability for the countries in consideration. The consumption of non-renewable energy sources is exposed to higher taxes in all net energy importing countries. Thus, the more non-renewable energy is consumed, the higher tax revenue is obtained, and the budget deficits gradually decrease.

This study makes a new way for subsequent researchers. The topic is kind a novel and deserves a detailed research. The present study does not consider the influence of aggregation bias, which is very difficult to overcome in panel data. Future studies, if done on a single-country-case, should also take this into account by appointing budget deficits by country as dependent variable. By doing so, it would be possible to compare the results of crosssections with the results provided by pooled panel to see if there is any bias.

Funding: This study received no specific financial support.

Competing Interests: The authors declare that they have no competing interests.

Acknowledgement: All authors contributed equally to the conception and design of the study.

\section{REFERENCES}

Alper, A., \& Oguz, O. (2016). The role of renewable energy consumption in economic growth: Evidence from asymmetric causality. Renewable and Sustainable Energy Reviews, 60(C), 953-959.

Apergis, N., Chang, T., Gupta, R., \& Ziramba, E. (2016). Hydroelectricity consumption and economic growth nexus: Evidence from a panel of ten largest hydroelectricity consumers. Renewable and Sustainable Energy Reviews, 62(C), $318-325$. 
Apergis, N., \& Payne, J. E. (2011). The renewable energy consumption-growth nexus in Central America. Applied Energy, 88(1), 343-347.

Apergis, N., \& Payne, J. E. (2012). Renewable and non-renewable energy consumption-growth nexus: Evidence from a panel error correction model. Energy Economics, 34(3), 733-738.

Aslan, A., Apergis, N., \& Topcu, M. (2014). Banking development and energy consumption: Evidence from a panel of Middle Eastern countries. Energy, 72(C), 427-433. Available at: https://doi.org/10.1016/j.energy.2014.05.061.

Bai, J., \& Kao, C. (2006). On the estimation and inference of a panel cointegration model with cross-sectional dependence. In: Baltagi, B.H. (Ed.), Panel data econometrics: Theoretical contributions and empirical applications. Amsterdam: Elsevier Science.

Barany, A., \& Grigonyte, D. (2015). Measuring fossil fuel subsidies, ECFIN economic brief. Retrieved from http://ec.europa.eu/economy_finance/publications/economic_briefs/2015/pdf/eb40_en.pdf. [Accessed 12/06/2016].

Bhattacharya, M., Paramati, S. R., Ozturk, I., \& Bhattacharya, S. (2016). The effect of renewable energy consumption on economic growth: Evidence from top 38 countries. Applied Energy, 162(C), 733-741.

Bildirici, M. E. (2013). Economic growth and biomass energy. Biomass and Bioenergy, 50, 19-24.

Bilgili, F., \& Ozturk, I. (2015). Biomass energy and economic growth nexus in G7 countries: Evidence from dynamic panel data. Renewable and Sustainable Energy Reviews, 49(C), 132-138.

Bulut, U., \& Menegaki, A. (2020). Solar energy-economic growth nexus in top 10 countries with the highest installed capacity. Energy Sources, Part B: Economics, Planning and Policy, 1-14.

Chang, T., Gupta, R., Inglesi-Lotz, R., Simo-Kengne, B., Smithers, D., \& Trembling, A. (2015). Renewable energy and growth: Evidence from heterogeneous panel of G7 countries using Granger causality. Renewable and Sustainable Energy Reviews, $52(\mathrm{C}), 1405-1412$.

Destek, M. A. (2016). Renewable energy consumption and economic growth in newly industrialized countries: Evidence from asymmetric causality test. Renewable Energy, 95(C), 478-484.

Dogan, E., \& Ozturk, I. (2017). The influence of renewable and non-renewable energy consumption and real income on CO 2 emissions in the USA: Evidence from structural break tests. Environmental Science and Pollution Research, 24(11), 1084610854 .

Dumitrescu, E. I., \& Christophe, H. (2012). Testing for granger non-causality in heterogeneous panels. Economic Modelling, 29(4), 1450-1460. Available at: https://doi.org/10.1016/j.econmod.2012.02.014

E.L. (2015). The global addiction to energy subsidies. Retrieved from http://www.economist.com/blogs/economistexplains/2015/07/economist-explains-19. [Accessed 04/05/2016].

European Commission. (2003). Council directive 2003/96/EC of 27 October 2003 restructuring the community framework for the taxation of energy products and electricity. Official Journal of the European Union, L 5 1-70.

Finnish Energy Industries. (2011). Energy taxation in Europe, Japan and the United States.Retrieved from: https://energia.fi/files/725/et_energiav_naytto_eng_040211.pdf. [Accessed 16/08/2020].

GovUK. (2016). Tax on shopping and services. Retrieved from https://www.gov.uk/tax-on-shopping/energy-saving-products. [Accessed 15/06/2016].

IMF. (2014). Fiscal policy to address energy environmental impacts. Retrieved from http://www.imf.org/external/pubs/ft/survey/so/2014/POL073114A.htm. [Accessed 13/05/2016].

International Energy Agency. (2016). Energy subsidies. Tracking the impact of fossil-fuel subsidies. Retrieved from: https://www.iea.org/topics/energy-subsidies. [Accessed 16/08/2020].

IPCC. (2016). Intergovernmental panel on climate change, climate change synthesis report. Retrieved from https://www.ipcc.ch/report/ar5/syr. [Accessed 13/05/2016].

Irandoust, M. (2016). The renewable energy-growth nexus with carbon emissions and technological innovation: Evidence from the Nordic countries. Ecological Indicators, 69, 118-125.

Kao, C., \& Chiang, M. H. (2000). On the estimation and inference of a cointegrated regression in panel data. Advances in Econometrics, 15, 179-222. 
Khan, M. A., Khan, M. Z., Zaman, K., Irfan, D., \& Khatab, H. (2015). Questing the three key growth determinants: Energy consumption, foreign direct investment and financial development in South Asia. Renewable Energy, 68(C), $203-215$.

Komal, R., \& Abbas, F. (2015). Linking financial development, economic growth and energy consumption in Pakistan. Renewable and Sustainable Energy Reviews, 44(C), $211-220$

Kumar, R. R., Stauvermann, P. J., Loganathan, N., \& Kumar, R. D. (2015). Exploring the role of energy, trade and financial development in explaining economic growth in South Africa: A revisit. Renewable and Sustainable Energy Reviews, 52, $1300-1311$.

Lin, B., \& Moubarak, M. (2014). Renewable energy consumption-economic growth nexus for China. Renerwable and Sustainable Energy Reviews, $40(\mathrm{C}), 111-117$.

Marques, A. C., \& Fuinhas, J. A. (2012). Is renewable energy effective in promoting growth? Energy Policy, 46(C), 434-442.

Marques, A. C., Fuinhas, J. A., \& Menegaki, A. N. (2016). Renewable vs non-renewable electricity and the industrial production nexus: Evidence from an ARDL bounds test approach for Greece. Renewable Energy, 96(PA), 645-655.

Marques., A. C., Fuinhas, J. A., \& Menegaki, A. N. (2014). Interactions between electricity generation sources and economic activity in Greece: A VECM approach. Applied Energy, 132(C), 34-46.

Menegaki, A. N. (2014). On energy consumption and GDP studies; A meta-analysis of the last two decades. Renewable and Sustainable Energy Reviews, 29(C), 31-36.

Menegaki, A. N., \& Tiwari, A. K. (2017). The index of sustainable economic welfare in the energy-growth nexus for American countries. Ecological Indicators, 72, 494-509.

Menegaki, A. N., \& Tugcu, C. T. (2016). Rethinking the energy-growth nexus: Proposing an index of sustainable economic welfare for Sub-Saharan Africa. Energy Research $\Xi^{\circ}$ Social Science, 17, 147-159. Available at: https://doi.org/10.1016/j.erss.2016.04.009.

Menegaki., A. N. (2011). Growth and renewable energy in Europe: A random effect model with evidence for neutrality hypothesis. Energy Economics, 33(2), 257-263.

Nampoothiri, M., \& Manoharan, H. (2014). Using trade policy to address renewable energy access challenges in Africa. BioRes (ICTSD, International Centre for Trade and Sustainable Development). Retrieved from: https://www.tralac.org/news/article/5774-using-trade-policy-to-address-renewable-energy-access-challenges-inafrica.html. [Accessed 15/08/2020].

NERA Economic Cosulting. (2014). Energy taxation and subsidies in Europe: A report on government revenues, subsidies and support measures for fossil fuels and renewables in the EU and Norway, Report for the International Association of Oil and Gas $\quad$ Producers. $\quad$ Retrieved from http://www.nera.com/content/dam/nera/publications/archive2/PUB_OGP_0514.pdf. [Accessed 08/05/2018].

Ocal, O., \& Aslan, A. (2013). Renewable energy consumption-economic growth nexus in Turkey. Renewable and Sustainable Energy Reviews, 28, 494-499. Available at: https://doi.org/10.1016/j.rser.2013.08.036.

OECD. (2013). Taxing energy use: A graphical analysis: OECD Publishing.

Ohler, A., \& Fetters, I. (2014). The causal relationship between renewable electricity generation and GDP growth: A study of energy sources. Energy Economics, 43, 125-139. Available at: https://doi.org/10.1016/j.eneco.2014.02.009.

OSCE. (2009). Framework conditions and international best practices for renewable energy support mechanisms. Retrieved from http://www.osce.org/files/documents/o/b/41339.pdf. [Accessed 15/03/2015].

Ozcan, B., \& Ozturk, I. (2019). Renewable energy consumption-economic growth nexus in emerging countries: A bootstrap panel causality test. Renewable and Sustainable Energy Reviews, 104(C), 30-37.

Pedroni, P. (2000). Fully modified OLS for heterogeneous cointegrated panels. Advances in Econometrics, 15, 93-130.

Pedroni, P. (2004). Panel cointegration: Asymptotic and finite sample properties of pooled time series tests with an application to the PPP hypothesis. Econometric Theory, 2O(3), 597-625. Available at: https://doi.org/10.1017/s0266466604203073.

Pesaran, M. H. (2004). General diagnostic tests for cross section dependence in pan-els. University of Cambridge, Faculty of Economics, Cambridge Working Papers in Economics No. 0435. 
Rafindadi, A. A., \& Ozturk, I. (2016). Effects of financial development, economic growth and trade on electricity consumption: Evidence from post-Fukushima Japan. Renewable and Sustainable Energy Reviews, 54, 1073-1084. Available at: https://doi.org/10.1016/j.rser.2015.10.023.

Saidi, K., \& Mbarek, M. B. (2016). Nuclear energy, renewable energy, CO2 emissions, and economic growth for nine developed countries: Evidence from panel Granger causality tests. Progress in Nuclear Energy, 88, 364-374. Available at: https://doi.org/10.1016/j.pnucene.2016.01.018.

Sebri, M. (2015). Use renewables to be cleaner: Meta-analysis of the renewable energy consumption-economic growth nexus. Renewable and Sustainable Energy Reviews, 42, 657-665. Available at: https://doi.org/10.1016/j.rser.2014.10.042.

Shahbaz, M., Rasool, G., Ahmed, K., \& Mahalik, M. K. (2016). Considering the effect of biomass energy consumption on economic growth: Fresh evidence from BRICS region. Renewable and Sustainable Energy Reviews, 6O(C), 1442-1450.

Sharif, A., Raza, S. A., Ozturk, I., \& Afshan, S. (2019). The dynamic relationship of renewable and nonrenewable energy consumption with carbon emission: A global study with the application of heterogeneous panel estimations. Renewable Energy, 133(C), 685-691.

Tang, C. F., \& Tan, B. W. (2014). The linkages among energy consumption, economic growth, relative price, foreign direct investment, and financial development in Malaysia. Quality \& Quantity, 48(2), 781-797.

UNEP. (2008). Reforming energy subsidies, opportunities to contribute to the climate change agenda. Retrieved from http://www.unep.ch/etb/publications/Energy\%20subsidies/EnergySubsidiesFinalReport.pdf. [Accessed 04/05/2016].

UNEP. (2011). Towards a green economy: Pathways to sustainable development and poverty eradication - a synthesis for policy makers. $\quad$ Retrieved from: $\quad$ www.unep.org/greeneconomy: https://sustainabledevelopment.un.org/content/documents/126GER_synthesis_en.pdf. [Accessed 16/08/2020].

Westerlund, J. (2007). Testing for error correction in panel data. Oxford Bulletin of Economics and Statistics, 69(6), 709-748.

Views and opinions expressed in this article are the views and opinions of the author(s), Asian Economic and Financial Review shall not be responsible or answerable for any loss, damage or liability etc. caused in relation to/arising out of the use of the content. 